\title{
Stay in solidarity and share equally: An open access journal in childhood studies
}

\author{
Mehmet Toran $^{*}$, Mesut Sackes ${ }^{* *}$, Mine Gol-Guven ${ }^{* * *}$
}

Journal of Childhood, Education \& Society (JCES) was founded as a product of collective thought under the leadership of Dr. Mehmet Toran in July 2019 by a group of early childhood researchers who conduct both collaborative and independent academic research. Under the light of scientific research, current publishing policies cannot eliminate inequalities in public access for transfer and access of knowledge that is generated for the public weal (Beall, 2013). Particularly, having a limited access to the knowledge in early childhood studies is acknowledged as the first step for constitution of JCES. In this context, we would like to underline that independent researchers who are voluntarily taking part in the emergence of JCES are involved in a very courageous endeavour. This collective constitution takes an important responsibility for the public as well, and we point out that to fulfil this responsibility, it embraces moral and ethical rules as a reference point. Objectives, scope and ethical principles of JCES are determined with the contribution of the editorial board. In addition, we make promise to the larger research community of early childhood area that we will make sure to contribute to the area by giving a priority to high quality of research with robust evidence.

JCES adopts open science perspective in early childhood studies. Therefore, JCES has a high opinion of sharing the knowledge among people who are in children's ecology democratically. Attaching importance to open science policy, JCES defends scientific knowledge as public property that should be shared with all without depressing its value (Tonta, 2015). In the light of this target, -as JCES editorial board- we believe that scientific information that has been produced as public property should be shared with everyone through open access. The scientific communication enhanced between researcherspractitioners-readers is aimed to put into practice through the "open access" method. In this context, as open access policy within JCES, we embraced non-profit, voluntary editorial operations without charging a fee either from the reader or authors. Our experiences during publishing our first issue promise that it can be put into practice with a collective movement voluntarily on a digital platform. Solidarity is possible to carry out editorial process not only in Turkey but also with a contribution from every corner of the world.

We have given extra importance to research ethics as our publishing policy. While specifying ethical principles, we aimed to take researcher's attention to this issue. In this sense, after discussions with EECERA and then with the permission from Trustees of EECERA, we decided to embrace EECERA Ethical Code for Early Childhood Researchers that is formulated by Chris Pascal, Tony Bertram, Julia Formosinho, Colette Gray and Margy Whalley (2012). The ethical code bears qualification as a guide for researchers working in the early childhood area. We would like to indicate that applicant articles to the JCES are also evaluated in terms of those ethical codes during the editorial preliminary consideration process.

After calling for papers for the inaugural issue, we had a considerable amount of article applications.

\footnotetext{
'Istanbul Kültür University, Faculty of Education, Department of Early Childhood Education, Istanbul, Turkey, e-mail: m.toran@iku.edu.tr; ORCID: https://orcid.org/0000-0003$\underline{3457-9113}$

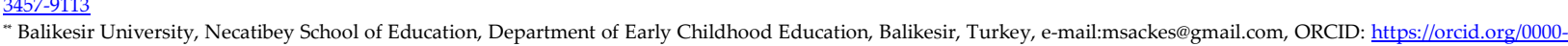
0003-3673-1668

"'Bogazici University, Faculty of Education, Department of Early Childhood Education, Istanbul, Turkey, e-mail: mine.golguven@boun.edu.tr, ORCID: https://orcid.org/0000$\underline{0002-1675-4478}$ 
Those applications studiously evaluated by the referees after preliminary considerations. In this process, constructive feedback from the referees and the revisions authors made in consideration to given feedback contributed to quality of articles concurrently to the quality of the journal. Peer review process that is held studiously, on time and constructively demonstrated that solidarity is built correctly and truthfully. Therefore, we would like to especially thank the referees for the inaugural issue.

As you will see in the journal, there are six articles for the inaugural issue from five different countries: Belgium, Colombia, Israel, Tanzania and the USA. This variety is a result of effective publicity of the journal by editorial board and efficient use of digital platforms with open access policy. Besides that, especially the call for papers announcements by EECERA in their member mail groups and social media accounts demonstrated once more how important solidarity is. As a result of this solidarity and cooperation, we would like to underline that the geographical variety of applicant articles strengthen our faith and self-confidence as well.

After publishing first issue, we will continue pertinaciously working to strengthen international collaborations and to ensure continuity of the journal. Being aware of responsibility we are carrying and the risks we may face in the process, we would like to state that we have already taken necessary precautions. To ensure long running path and continuity of publishing for the journal, Gizem Alvan, Kerem Avcr and Taibe Kulaksız - doctorate students- have already started gaining experience in journal publishing and editorial administration process. These experiences would play an important role to provide sustainable publication of the journal. We would like to congratulate them to take part in a constitution courageously.

We would like to thank all partners who contributed to spreading information to publish interest with open access with their articles and their supports in the editorial process for the inaugural issue. We would like to state that the call for papers continues for the second issue of JCES which will be published in August 2020 and we are open to early childhood researchers' original contributions.

\section{Declarations}

Acknowledgements: Special thanks to Dr. Ramazan Sak for reading and corrections. Authors' contributions: All authors have equal contribution.

Competing interests: The authors declare that they have no competing interests.

Funding: This paper was not funded by any funding agency or grant.

\section{References}

Beall, J. (2013). The open-access movement is not really about open access. tripleC: Communication, Capitalism E Critique. Open Access Journal for a Global Sustainable Information Society, 11(2), 589-597. https://doi.org/10.31269/triplec.v11i2.525

Bertram, T., Formosinho, J., Gray, C., Pascal, C., \& Whalley, M. (2016). EECERA ethical code for early childhood researchers. European Early Childhood Education Research Journal, 24(1), iii-xiii. https://doi.org/10.1080/1350293X.2016.1120533

Tonta, Y. (2015). Açık bilim ve açık erişim. In U. Al and Z. Taşkın (Eds). Prof. Dr. İrfan Çakın'a Armağan, (pp. 235-250). Ankara: Hacettepe Üniversitesi Bilgi ve Belge Yönetimi Bölümü. 